\title{
Accelerated ripening of Ras cheese with a commercial proteinase and intracellular enzymes from Lactobacillus delbrueckii subsp bulgaricus, Propionibacterium freudenreichii and Brevibacterium linens
}

\author{
N Ezzat \\ Department of Agricultural Industries, Faculty of Agriculture, \\ Alexandria University, Alexandria, Egypt
}

(Received 14 May 1990; accepted 18 July 1990)

\begin{abstract}
Summary - Intracellular cell-free enzyme extract of Lactobacillus delbrueckii subsp bulgaricus, Propionibacterium freudenreichii and Brevibacterium linens, was used to accelerate Ras cheese ripening with a commercial proteinase Neutrase. The general gross composition of the cheese was very similar during the ripening period. Significant increase in the free fatty acids of the cheese manufactured with the cell-free extract of Lactobacillus delbrueckii subsp bulgaricus was observed; protein breakdown showing little difference between the control and the treated cheese. After storage, the cheese treated with either Neutrase alone or with cell-free extract had significantly more intense typical Ras cheese flavour, but the presence of Neutrase and cell-free extract gave more bitterness at the end of ripening.
\end{abstract}

Ras cheese / acceleration / Neutrase / Lactobacillus delbrueckii subsp bulgaricus / Propionibacterium freudenreichii/ Brevibacterium linens

Résumé - Accélération de l'affinage du fromage Ras à l'aide d'une protéase commerciale et d'enzymes intracellulaires de Lactobacillus delbrueckii subsp bulgaricus, Propionibacterium freudenreichii et Brevibacterium linens. Des extraits intracellulaires de Lactobacillus delbrueckii subsp bulgaricus, de Propionibacterium freudenreichii et de Brevibacterium linens ont été utilisés avec la Neutrase commerciale pour accélérer l'affinage du fromage Ras. La composition globale des fromages était très similaire au cours de l'affinage. Cependant, on observait une augmentation significative de la teneur en acides gras libres pour les fromages contenant l'extrait intracellulaire de Lactobacillus delbrueckii subsp bulgaricus. Par contre, on notait peu de différence en ce qui concerne l'hydrolyse des protéines entre les fromages témoins et les essais. Au cours de la conservation, les fromages contenant la Neutrase soit seule, soit avec les extraits cellulaires, avaient une flaveur typique du fromage Ras significativement plus intense, mais conduisaient à plus d'amertume à la fin de l'affinage.

fromage Ras / accélération de l'affinage / Neutrase / Lactobacillus delbrueckii subsp bulgaricus / Propionibacterium freudenreichii / Brevibacterium linens 


\section{INTRODUCTION}

The Ras cheese is an Egyptian hard cheese made from cow and buffalo milk. The composition of the cheese has been described by Hofi et al (1970). Ras cheese has been the object of numerous research programmes involving the use of commercial preparation of proteinases and lipases.

Addition of aged Lactobacillus helveticus cells to Ras cheese was reported to increase protein breakdown and to improve the organoleptic properties of the cheese (Nassib, 1974). El Shibiny et al (1978) studied the influence of pre-gastric lipases on the ripening and flavour development of Ras cheese. Magdoub et al (1979) reduced the ripening period of Ras cheese to $50 \%$ by adding cell-free filtrates from Bacillus circulans milk culture.

Abdel Salam et al (1979) attempted to accelerate Ras cheese fabrication using a blend of Mucor pusillus proteinase, pregastric lipase Capalase $\mathrm{K}$, and fungal esterase lipase $\mathrm{C}_{12 / 5}$. The addition of small amounts of the enzymes improved the quality of the cheese with little or no flavour defects. The enzyme mixtures led to increases in free volatile fatty acid concentrations. An attempt to accelerate the ripening of Ras cheese with a heat-shocked culture of either Lactobacillus casei or L helveticus (Abdel-Baky et al, 1986) did not greatly affect cheese proximate substances in global cheese composition but influenced the flavour intensity, the body and the formation of soluble $\mathrm{N}$ compounds and free volatile fatty acids. Total proteoIytic and lipolytic bacterial counts also increased. Cheese containing heat-shocked Lactobacilli showed desirable flavour and consistency one to two months earlier than control cheese.
Rabie et al (1986) enhanced flavour development in Ras cheese made by direct acidification by the addition of cheese slurry or starter, which gave bacterial counts similar to those in control cheese. The additions accelerated the ripening as assessed by soluble, non protein or amino $\mathrm{N}$. They equally increased the lipolysis, particularly with cheese slurry, yielding the best flavour scores.

Abou El-Ella et al (1986) attempted to produce Ras cheese by direct acidification using either lactic or citric acid of pH 5.8. Direct acidified cheese was characterized by poor body, crumbly texture and weak flavour. Cheese made by citric acid acidification was more acceptable than that produced with lactíc acid.

El-Neshawy et al (1986) used milk with 1 or $1.5 \%$ fat and $0.02 \%$ carrageenan for the preparation of Ras cheese curd, which was then mixed with $2 \%$ starter culture (containing Streptococcus lactis subsp diacetylactis and Lactobacillus casei) and 10 $\mathrm{ml}$ of $0.05 \% \mathrm{MnCl}_{2}$ solution $/ \mathrm{kg}$ curd or reduced glutathione at $100 \mathrm{mg} / \mathrm{kg}$ curd. The additives enhanced flavour intensity, improved body characteristics and accelerated the formation of soluble $\mathrm{N}$ compounds and free volatile fatty acids. To influence normal body texture development, El Soda et al (1990) used Lactobacillus helveticus and Lactobacillus casei cell-free extract to accelerate Ras cheese ripening.

This study aims to accelerate Ras cheese ripening by adding enzyme systems obtained from Lactobacillus delbrueckii subsp bulgaricus, Propionibacterium freudenreichii and Brevibacterium linens, known for their active proteinase, peptidase and esterase systems (EI Soda and Desmazeaud, 1982; El Shafei et al, 1989 ), and with the proteolytic preparation Neutrase. 


\section{MATERIALS AND METHODS}

\section{Cheesemaking}

Ras cheese was manufactured in the dairy plant of the University of Alexandria according to Hofi et al (1970) with some modifications: Friesian cow milk obtained from the farm of the Faculty of Agriculture, Alexandria University, was used for Ras cheese manufacture. The fat content was standardized to $3 \%$. The milk was filtrated and pasteurized, and $1 \%$ of a pure starter culture of Streptococcus cremoris (Hansen Laboratory, Denmark) added. Milk was coagulated in 40 min using Fromase 200 microbial rennet from Mucor miehei obtained from Rapidase, France.

The resulting coagulum was cut and the curd heated and stirred for $45 \mathrm{~min}$. When the temperature reached $45^{\circ} \mathrm{C}$ and the whey activity $0.14 \%$, the scalding step was stopped. About $1 / 3$ of the whey was drawn off and commercial salt added at the rate of $3 \%$. The whey was completely drawn off and the curd was divided into 5 equal portions and enzyme preparations premixed with the correct amount was added to each curd batch immediately before pressing. One curd portion was left untreated as a control.

\section{Enzymes}

Neutrase (Novo Enzyme Products Ltd, Windsor, Berks, UK) is a neutral metalloproteinase obtained from Bacillus subtilis and supplied as a spray-dried powder. It was added at the doserate of $80 \mathrm{mg} / \mathrm{kg}$ of milk.

Lactobacillus delbrueckii subsp bulgaricus CNRZ 369, Propionibacterium freudenreichii CNRZ p23 and Brevibacterium linens CNRZ 906 were used for this study. Culturing of the organisms and preparation of the crude cell free extract were carried out as described by $\mathrm{EI}$ Soda et al (1982) and El Soda and Desmazeaud (1982).

\section{Chemical analysis}

Fat was determined according to the butyrometer Gerber method. Moisture was determined by oven drying at $105^{\circ} \mathrm{C}$. The $\mathrm{pH}$ was measured by directly probing the cheese homogenate with a glass electrode. Determination of total nitrogen and soluble nitrogen were measured by the Kjeldahl method.

In addition to soluble nitrogen determination, the procedure described by Rakshy et al (1974), and the method described by Godinho and Fox (1981) were used to follow the ripening of the curds.

\section{Organoleptic assessment}

Flavour intensity and description were evaluated using, as general guide, the flavour scores and criticism proposed by Kosikowski and Iwasaki (1975) with zero indicating flavour defects and 5 indicating strong favourable flavour.

\section{RESULTS AND DISCUSSION}

\section{Total composition of cheese after 8 weeks}

The general composition of the 5 curds was very similar during the ripening period and close to a normal Ras cheese. The mean values of fat analysis, dry matter, $\mathrm{pH}$ and total proteins for the 5 curds at the end of the ripening period were: $31.6,62.0,5.4$ and 24.3. The combination Neutrase plus cell free extracts showed no advantage over Neutrase alone (table I). Similar observations were also reported by Law and Wigmore (1983) and El Soda et al (1981, 1982, 1990).

\section{Lipolysis}

The results reported in figure 1 show a significant increase in the free fatty acids of the curds manufactured with the cell-free extracts when compared to the control or 
Table I. Technological characteristics of Ras cheese. A: Control. B: Neutrase. C: Neutrase + Propionibacterium freudenreichii P23. D: Neutrase + Brevibacterium linens CNRZ 906. E: Neutrase + Lactobacilus delbrueckii subsp bulgaricus CNRZ 369. - : not determinated.

Caractéristiques technologiques du fromage Ras.

\begin{tabular}{|c|c|c|c|c|c|c|c|c|c|c|c|c|c|c|c|c|c|c|c|c|}
\hline \multirow{2}{*}{$\begin{array}{l}\text { Ripening } \\
\text { time } \\
\text { (weeks) }\end{array}$} & \multicolumn{5}{|c|}{ Fat } & \multicolumn{5}{|c|}{ Dry matter } & \multicolumn{5}{|c|}{$p H$} & \multicolumn{5}{|c|}{ Total protein } \\
\hline & $A$ & $B$ & $C$ & $D$ & $E$ & $A$ & $B$ & $C$ & $D$ & $E$ & $A$ & $B$ & $C$ & $D$ & $E$ & $A$ & $B$ & $C$ & $D$ & $E$ \\
\hline 0 & 26.5 & 27.0 & 26.0 & 25.0 & 26.0 & 53.0 & 52.6 & 53.3 & 51.3 & 54.0 & 5.75 & 5.75 & 5.85 & 5.90 & 5.90 & 22.1 & 21.4 & 21.4 & 20.3 & 21.4 \\
\hline 2 & 27.0 & 28.0 & 27.0 & 21.0 & 26.6 & 56.3 & 58.6 & 57.2 & 55.2 & 58.2 & 5.60 & 5.55 & 5.36 & 5.55 & 5.60 & 22.1 & 21.4 & 22.1 & 21.4 & 22.8 \\
\hline 4 & 27.0 & 28.0 & 29.0 & 29.0 & 28.0 & - & 62.9 & 61.3 & 60.4 & 59.8 & 5.55 & 5.45 & 5.35 & 5.45 & 5.55 & 20.3 & 21.7 & 22.0 & 22.8 & 21.0 \\
\hline 6 & 27.0 & 28.0 & 33.0 & 32.0 & 30.0 & 60.3 & 59.8 & 63.2 & 63.4 & 62.14 & 5.30 & 5.45 & 5.40 & 5.43 & 5.26 & - & 22.1 & 23.5 & 25.0 & - \\
\hline 8 & 30.0 & - & 33.0 & 32.0 & - & 60.0 & 62.7 & 63.4 & 63.0 & 61.12 & 5.48 & 5.39 & 5.58 & 5.75 & 4.91 & 24.2 & 23.9 & 23.9 & 25.3 & 24.2 \\
\hline Means & \multicolumn{5}{|c|}{$31.6 \%$} & \multicolumn{5}{|c|}{$62.0 \%$} & \multicolumn{5}{|c|}{5.4} & \multicolumn{5}{|c|}{$24.3 \%$} \\
\hline
\end{tabular}



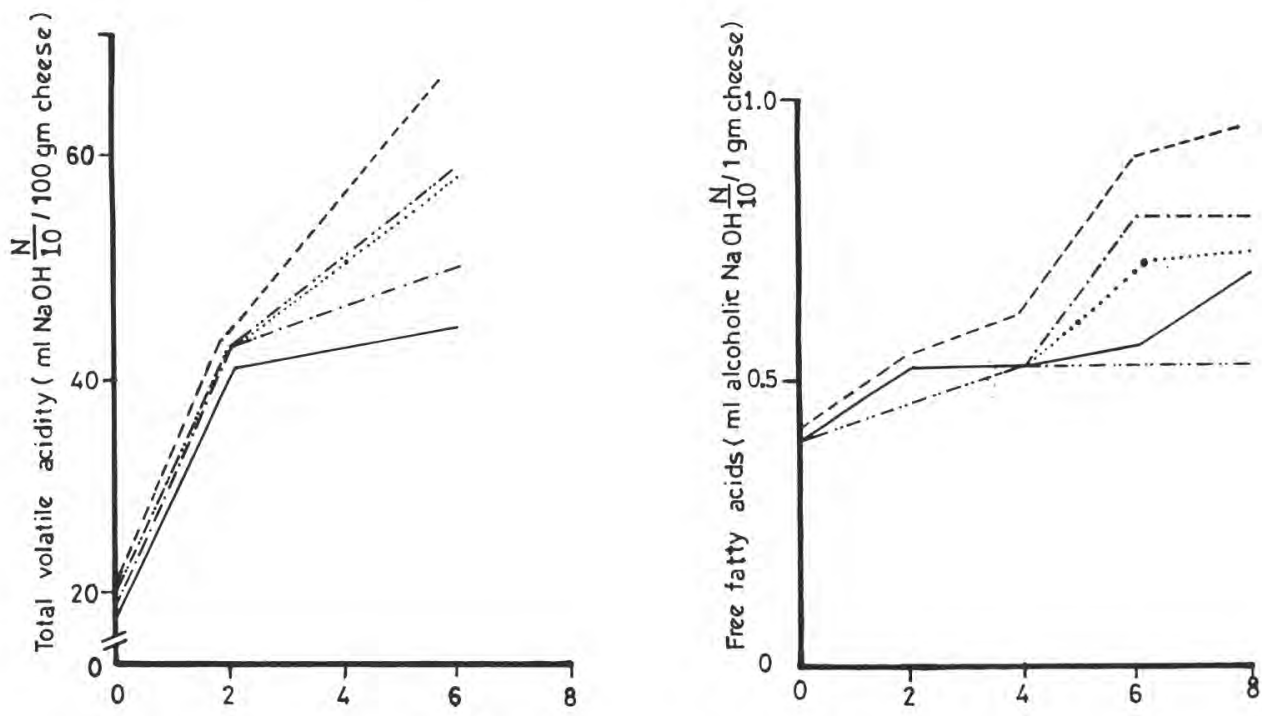

Ripening time (weeks)

Fig 1. Evaluation of total volatile acidity and free fatty acids during ripening. Control; - - - Neutrase; - . - . Neutrase + Propionibacterium freudenreichii CNRZ p23; - - - - Neutrase + Brevibacterium linens CNRZ 906; - - - Neutrase + Lactobacillus delbrueckii subsp bulgaricus CNRZ 369.

Evaluation des acides volatils totaux et des acides gras libres pendant l'affinage.

the Neutrase. When comparing the three microorganisms used in this investigation, it appears that a high rate of ripening is obtained with Lactobacillus delbrueckii subsp bulgaricus, a species shown to have highly lipolytic and proteolytic activity (El Soda et al, 1984).

\section{Protein breakdown}

Soluble nitrogen fraction (fig 2), was similar in controls and treated cheese. The addition of crude cell-free extracts of Lactobacillus delbrueckii subsp bulgaricus, Propionibacterium freudenreichii and Brevibacterium linens to Neutrase showed little effect on the amount of soluble nitrogen liberated from the cheese. Law and Wigmore (1983) as well as El Soda et al (1990) reported that the cell free extract did not show measurable increase in gross proteolysis or trichloroacetic acid (TCA)soluble nitrogen in cheese.

\section{Flavour}

After storage for one month, the cheese treated with either Neutrase or cell-free extracts had significantly more intense typical Ras cheese flavour than untreated control cheese (table II). Cheese containing both Neutrase and cell-free extract had a stronger flavour than cheese treated with Neutrase alone. 


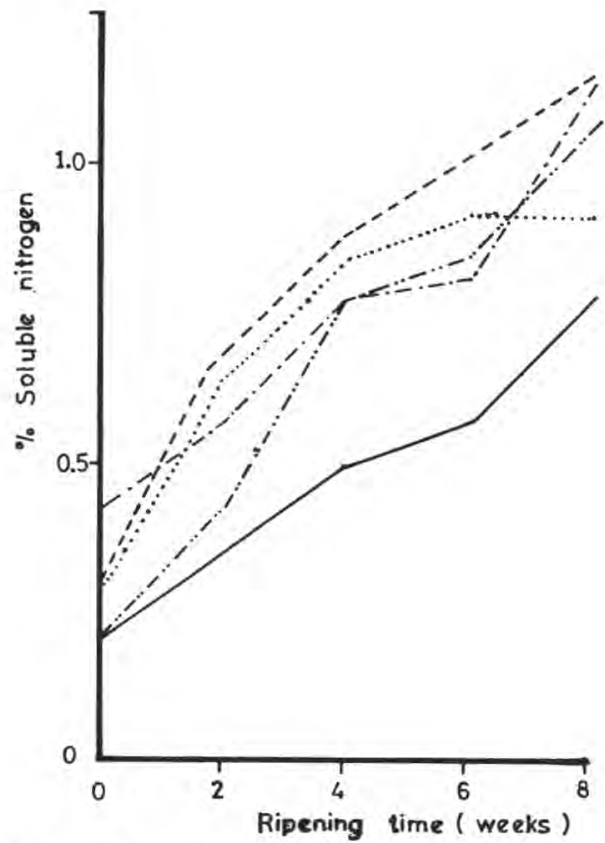

Fig 2. Evaluation of soluble nitrogen during cheese ripening. - Control; - - - N Neutrase; - ..- Neutrase + Propionibacterium freudenreichii CNRZ p23; - - - - - Neutrase + Brevibacterium linens CNRZ 906; - - - Neutrase + Lactobacillus delbrueckii subsp bulgaricus CNRZ 369.

Evaluation de l'azote soluble pendant l'affinage.

Increased bitterness after two months of ripening is due to the presence of cellfree extract in the treated cheese.

Comparing the three microorganisms used in this investigation, we observed that the cheese treated with Lactobacillus delbrueckii subsp bulgaricus has typical Ras cheese flavour during ripening, except for the bitterness mentioned above.

This study confirms the intensifying effect of Neutrase on the flavour of Ras cheese. Additional enzyme of starter bac- teria in the form of an intracellular extract are promising, since ripening time could be reduced by $1 / 4$ by adding the enzymes. The intracellular extract equally increased the flavour intensity in young cheese. The only measurable effect of cell-free extracts was the bitter flavour appearing at the end of the ripening time. This phenomenon remains a problem; we speculated that the bitterness detected in the Lactobacillus delbrueckii subsp bulgaricus extract curd was due to its complex peptidase system. We therefore used microorganisms with a less complex peptidase system, like Propionibacterium freudenreichii and Brevibacterium linens. But the cheese preparation still had the bitter taste. Apparently, it was not only related to complexity of the enzyme system used, but also to the direct addition of lactic bacterial enzymes to cheese curd.

Similar observations were reported by El Soda et al (1982): cell free extracts of Lactobacilli enhanced bitterness in cheese when incorporated in Cheddar cheese. Further work will be carried out in our laboratory by adding either heat-shocked microorganisms to cheese milk as an adjunct to starter bacteria, in order to determine their effect on proteolysis and flavour development in cheese, or freezing bacterial cells at suboptimal temperatures to injure the cell wall and membrane, inducing cell lysis. Substantial loss of acid production from freeze injury suggests that this procedure can be applied to add lactic acid bacteria to the milk without altering acid production during cheese processing.

We conclude that Lactobacilli species and especially Lactobacillus delbrueckii subsp bulgaricus can be added successfully to cheese such as Ras to enhance flavour development at initial stages of ripening without detrimental effect on the cheese processing and quality. 
Table II. The organoleptic properties of Ras cheese. A: Control. B: Neutrase. C: Neutrase + Propionibacterium freudenreichii P23. D: Neutrase + Brevibacterium linens CNRZ 906. E: Neutrase + Lactobacillus delbrueckii subsp bulgaricus CNRZ 369.

Propriétés oganoleptiques du fromage Ras.

\begin{tabular}{llllll}
\hline $\begin{array}{l}\text { Ripening } \\
\text { time (weeks) }\end{array}$ & 0 & 2 & 4 & 6 & 8
\end{tabular}

$\begin{array}{cccccc}\begin{array}{c}\text { Treat- } \\ \text { ment }\end{array} & \begin{array}{c}\text { Total Rancidity } \\ \text { (5) } \begin{array}{c}\text { and } \\ \text { bitterness }\end{array}\end{array} & \begin{array}{c}\text { Total Rancidity } \\ \text { and } \\ \text { bitterness }\end{array} & \begin{array}{c}\text { Total Rancidity } \\ \text { and } \\ \text { bitterness }\end{array} & \begin{array}{c}\text { Total Rancidity } \\ \text { and } \\ \text { bitterness }\end{array} & \begin{array}{c}\text { Total Rancidity } \\ \text { and }\end{array} \\ & & \text { bitterness }\end{array}$

\begin{tabular}{lllllllllll}
\hline $\mathrm{A}$ & 2.1 & - & 1.8 & - & 2.3 & - & 3.3 & - & 3.3 & - \\
$\mathrm{B}$ & 2.3 & - & 1.7 & - & 2.8 & - & 2.5 & $\mathrm{Bit}^{+}$ & 2.8 & - \\
$\mathrm{C}$ & 2.5 & - & 2.8 & - & 3.0 & $\mathrm{Bit}^{+}$ & 2.3 & $\mathrm{Bit}^{+}$ & 2.3 & $\mathrm{Bit}^{++}$ \\
$\mathrm{D}$ & 2.2 & - & 2.7 & - & 3.3 & - & 1.8 & $\mathrm{Bit}^{+}$ & 1.5 & $\mathrm{Bit}^{+++}$ \\
$\mathrm{E}$ & 2.3 & - & 2.5 & - & 2.9 & - & 3.2 & - & 4.0 & $\mathrm{Bit}^{+}$ \\
\hline
\end{tabular}

\section{ACKNOWLEDGMENTS}

The author would like to thank $\mathrm{H}$ Zaki and $\mathrm{M}$ EI Soda for useful advice as well as N Zayada for technical assistance.

\section{REFERENCES}

Abdel-Baky A, El-Neshawy A, Rabie A, Ashour M (1986) Heat-shocked Lactobacilli for accelerating flavour development of Ras cheese. Food Chem 21, 301-313

Abdel-Salam M, Mohamed A, Ayad E, Fahmy N, El Shibiny S (1979) Changes in the quality and chemical composition of Ras cheese by some commercial enzyme preparations. Egypt J Dairy Sci 7, 63-74

Abou-El-Ella, El Neshawy A, Rabie A, Emara E (1986) An attempt to produce Ras cheese by direct acidification. Food Chem 19, 81-91

El Neshawy A, Abdel Baky A, Rabie A, Ashour M (1986) An attempt to produce low fat Caphalotyre (Ras) cheese of acceptable quality. Food Chem 22, 123-137
El Shafei H, Ezzat N, El Soda M (1989) The esterolytic activity of several strains of Brevibacterium linens. Egypt J Dairy Sci 17, 171179

El Shibiny S, Soliman M, El Bagowry E, Gad A, Abdel Salam M (1978) Development of volatile fatty acids in Ras cheese. J Dairy Res 45, 497-500

El Soda M, Desmazeaud M (1982) Les peptidehydrolases de Lactobacilles du groupe thermobacterium. I. Mise en évidence de ces activités chez Lactobacillus helveticus, $L$ lactis et $L$ bulgaricus. Can J Microbiol 28, 11811188

El Soda M, Desmazeaud M, Abou-Donia S, Kamal N (1981) Acceleration of cheese ripening by the addition of whole cells or cell free extracts from $L$ casei to the cheese curd. Milchwissenschaft 36, 140-142

El Soda M, Desmazeaud M, Abou Donia S, Badran A (1982) Acceleration of cheese ripening by the addition of extracts from $L$ helveticus, $L$ bulgaricus and $L$ lactis to the cheese curd. Milchwissenchaft 37, 325-327

El Soda M, Abdel Wahab H, Ezzat N, Ismail A (1984) The esterolytic and lipolytic activities 
of Lactobacilli from the thermobacterium group. J Dairy Sci 66, suppl-1, 68-74

El Soda M, Ezzat N, El Abassy F, Wahba A, Hassanein S (1990) Acceleration of Ras cheese ripening. II. Combination of a gross proteolytic agent with the cell free extract of some Lactobacilli. Egypt J Dairy Sci 18, 171182

Godinho M, Fox PF (1981) Ripening of Blue cheese. Influence of salting rate on lypolysis and carbonyl formation. Milchwissenschaft $36,476-481$

Hofi A, Youssef E, Ghoneim N, Tawab G (1970) Ripening changes in Caphalotyre (Ras) cheese manufactured from raw and pasteurized milk with special reference to flavour. J Dairy Sci 53, 1207-1214

Kosikowski F, Iwasaki T (1975) Changes in Cheddar cheese by commercial proteinase and intracellular enzymes from starter Streptococci. J Dairy Res 50, 519-525
Law B, Wigmore A (1983) Accelerated ripening of Cheddar cheese with a commercial proteinase and intracellular enzymes from starter Streptococci. J Dairy Res 50, 519-525

Magdoub M, Shehata A, Fayed E, Hofi A (1979) Effect of filtrates from milk cultures of some proteolytic spore forms the bacteriological quality of Ras cheese during ripening. Dairy Ind 56, 137-148

Nassib T (1974) Acceleration of Ras cheese ripening by autolyzed starter. Assiut J Agric Sci $5,123-129$

Rabie A, El Neshawy A, Abdel-Baky A, Abou El Ella W, Emara E (1986) Enhancement of flavour development in Ras cheese made by direct acidification. Food Chem 21, 5-16

Rakshy S, El Soda M, Tahon M (1974) Detection of straight chain $\left(\mathrm{C}_{2}-\mathrm{C}_{8}\right)$ carboxylic acid in cheese by thin layer chromatographic method. Indian J Dairy Sci 27, 74-79 